\title{
Quality of Work Life and Turnover Intention: A Partial Least Square (PLS) Approach
}

\author{
Lilis Surienty $\cdot$ T. Ramayah $\cdot$ May-Chiun Lo $\cdot$ Azlin Natasha Tarmizi
}

Accepted: 15 October 2013/Published online: 25 October 2013

(C) Springer Science+Business Media Dordrecht 2013

\begin{abstract}
The purpose of this study is to model the relationship of quality of work life factors and turnover intention among accounting professionals in Malaysia. Data was collected using a structured questionnaire gleaned from the literature. The data was analyzed using Smart Partial Least Squares a second generation structural equation modeling software. The results indicate that supervisory behavior, job characteristics and work life balance all have a significant negative relationship with turnover intention with work life balance the most significant predictor of turnover intention. Implications from this research is further explored.
\end{abstract}

Keywords Quality of work life - Turnover intention · Accounting professionals · Survey $\cdot$ PLS approach

\section{Introduction}

The number of two income households in Malaysia is heightening as women's involvement in the Malaysian workforce has increased to 3.7 million in 2006 as compared to only 2.7 million in the previous year ("3.7 juta wanita bekerja" 2007). This increases a concern for employees to achieve quality of work life, as both males and females are independently

L. Surienty $(\bowtie) \cdot T$. Ramayah

School of Management, Universiti Sains Malaysia, 11800, Minden, Pulau Pinang, Malaysia e-mail: lilis@usm.my

M.-C. Lo

Business and Management Department, Faculty of Economics and Business, Universiti Malaysia Sarawak, 94300 Kota Samarahan, Sarawak, Malaysia

A. N. Tarmizi

Coca-Cola Refreshments Malaysia Sdn Bhd, PT486, Persiaran Teknologi 4, Techpark@Enstek, 71760 Bandar Enstek, Negeri Sembilan, Malaysia 